\title{
NEW SPACES FOR CHANGE: POLICY CHALLENGES AND OPPORTUNITIES OFFERED BY DEVOLUTION IN THE UK
}

\author{
Stirbu Diana S. \\ Dr., Ph.D., London Metropolitan University, \\ 166-220 Holloway Road, London, N7 8DB, United Kingdom. \\ E-mail: d.stirbu@londonmet.ac.uk
}

\begin{abstract}
Modern state governance in Western Europe has undergone significant changes in the past thirty years. The horizontal shake-up triggered by new public management was complemented by a vertical shake-up of governance systems, fuelled by the European integration process and the increasingly prominent role of the regions both in economic development and in democratic renewal. The devolution process in the UK represents one of the most significant constitutional reforms of the British governance system, with deep political, administrative and policy implications. Drawing on a nine year old longitudinal study of the unfolding of the devolution process in the UK, this article explores the challenges and opportunities offered by the new political spaces created by devolution. The argument put forth in this paper is that devolution, whilst acting as a catalyst for differentiation and innovation both at process and output level, has lacked strategic vision in the re-shaping of the policy framework of the UK, thus exposing serious limitations of the current governance system, especially in terms of public scrutiny and accountability of the new governance frameworks, but also in terms of long term sustainability.
\end{abstract}

Keywords: regionalism; devolution; policy fragmentation; spaces for changes; multi-level governance.

\section{Introduction}

Modern state governance has undergone significant changes in the last thirty years as a result of a deep entrenchment of the neo-liberal orthodoxy and its associated reforms in Western democracies - new public management and of the increased socio, economic and political interconnectedness resulting from globalisation and, in the European context, from the integration process. The United Kingdom, arguably, pioneered some of the new public management rhetoric and practice as successive governments since the 1980s sought to redraw the boundaries of the state, its role in economic development and in rolling back the bureaucratic machinery of the welfare state (Rhodes, 1996). Moreover, since 1973, when it became a member of the European Community, the UK 
has also absorbed the dynamics of the European integration process (Bache and Marshall, 2004; Bache, 2007). More recently, since 1997 when the devolution process was launched, the United Kingdom's political, administrative and policy landscape has become increasingly fragmented and the new devolved administrations have pursued different policy directions (Adams and Robinson, 2002; Adams and Schmuecker, 2006).

Traditionally, the UK, despite its multi-national status and the asymmetry between the historic regions of England, Scotland, Wales and Northern Ireland, has presented strong features of a heavily centralised unitary state (Keating, 2010). The policy making machinery, heavily concentrated in Whitehall departments in London, has often been described in public administration literature as mostly opaque, bureaucratic, and centralised (Rowlands, 1998). The governance of the UK relied on a strong central government, deriving its support and legitimacy from a constitutional setup anchored in a majoritarian system -thus favouring strong executives-, ministerial responsibility and parliamentary sovereignty as underlying constitutional principles.

The first wave of modernisation of the British governance system included a horizontal shake-up of government infrastructure and processes triggering what in academic literature is often contextualised as the paradigmatic shift from 'government' to 'governance, from hierarchies to quasi-markets and networks (Osbourne and Gaebler, 1992; Rhodes, 1996). Public sector reforms such as privatisation, agentification and the co-option of the private sector into the delivery of public services prompted new ways and new labels for the means of conducting government business: 'steering, not rowing' (Osbourne and Gaebler, 1992), new public management, joined-up government etc (Flynn, 2001). More recently, the rhetoric of new public governance features co-production to describe the new dynamics between design and implementation of public services and the interconnectedness between the public, the private and the third sector (Bovaird, 2006; Pestoff, 2013).

A second wave of modernisation of the British governance landscape, which forms the focus of this article, marks the vertical re-configuration of the British state. This article distinguishes between two stages in this vertical shake-up of the British governance system, marked by the process of devolution. First generation devolution was launched in 1997 in Scotland, Wales and Northern Ireland. The process, highly political and constitutional in nature, has been largely a topdown process dominated arguably by compromise and lack of vision (McAllister and Stirbu, 2015). It created a new tier of democratic politics in Scotland, Wales and Northern Ireland and has essentially re-shaped the UK as a multi-level, quasi-federal system of governance Bogdanor, 2003). Arguably, the context has been set by transformations within the European Community, where regional and cohesion policies emphasised the role of regional or mezzo-level decision making (Hooghe, 1996; Benz and Eberlein, 1999; Hooghe and Marks, 2001). Moreover, the principle of subsidiarity, introduced under the Treaty of Maastricht, has fuelled a discourse that focuses on regional empowerment (Web and Collis, 2000) rather than on the primacy of the central government in economic development and planning. In the UK, these trends were also coupled with at- 
tempts to silence nationalist demands arising in Scotland and Wales, revitalise the democratic process, and better accommodate the diversity within the Union (Bogdanor, 2001).

The second generation devolution -to English cities and counties- is a form of co-ordinated localism and decentralisation of power, driven by economic growth aspirations as well as survival instincts within the context of deepening austerity in the UK and the toughening of central government (Stirbu, 2015). The process, fragmented and piecemeal so far, started in November 2014, when the Greater Manchester Combined Authority secured an extensive devolution package with the UK Treasury, closely followed by Sheffield City region. In line with the government's Northern Powerhouse rhetoric supporting growth in North England as a counterbalance to London's economic dominance, the Devolution to Cities and Counties Bill 2015-16 was introduced in Parliament after the Conservatives' electoral success in May 2015. This second generation (English) devolution, although essentially very different to that in Scotland, Wales and Northern Ireland, as it seeks to address mainly economic rather than democracy deficits, contributes nevertheless to the complexity of the governance framework in the United Kingdom.

The spatial fragmentation of the policy landscape arising from devolution and decentralisation led to a diversification and territorialisation of policy spaces, actors and processes (Keating et al 2009). The consequences in terms of output and outcomes, especially from the perspective of first generation devolution, have largely been accounted for from different perspectives. Some focus on policy differentiation and policy transfer within the UK's nations (Loughlin and Skyes, 2004; Keating, 2003, 2006; Keating and McEwan, 2005), whilst others focus on innovation and divergence in specific policy areas in the realm of social care, care for the elderly, social justice, and education (Greer, 2004).

Nonetheless, there is a deficit of reflection upon devolution's transformational capacity at the level of institutional structures and processes. This article explores some of the challenges and opportunities offered by these new political spaces created as a result of the asymmetric process of devolution in the UK. The argument put forth in this paper is that devolution, whilst acting as a catalyst for differentiation and innovation both at process and output level, has lacked strategic vision in the re-shaping of the policy framework of the UK, thus exposing serious limitations of the current governance system, especially in terms of public scrutiny and accountability of the new governance frameworks, but also in terms of long term sustainability.

Drawing on a seven year longitudinal study on the UK devolution process, this article provides, first, an overview of the governance landscape of the UK and its constituent regions. It will then focus on the vertical shake-up triggered by the process of devolution by outlining some of the innovation through devolution from a Welsh and Scottish perspective with a focus on policy process differentiation and integration of services. Additionally, the paper will overview some of the major challenges presented by the advent of these new spaces for change in the policy landscape of the UK and will draw lessons for countries that are currently undergoing decentralisation reforms. 
This article uses multi-level governance as a theoretical background, and advances the 'spaces for change' perspective as a tentative framework for conceptualising and explaining the variants of governance patterns that exist across the United Kingdom and the shifting locus of decision making from central governments to multi-actor arenas.

\section{Devolution and the fragmentation of the policy} arena in the UK

Devolution was launched in 1997 by the then newly elected Labour government. The process involved the creation of new democratically elected and accountable institutions in Scotland, Wales and Northern Ireland which enjoyed various degrees of power, featured different electoral systems and different ways of operating. The three institutions are also different in size and in the way the transfer of their functions was achieved. The Scottish Parliament, arguably the most advanced form of devolution in the UK (Bogdanor, 2003), enjoyed -from the very start- tax-varying powers and had a clear legislative system delineating reserved and devolved powers. At the other end of the spectrum, Wales was noticeably the least developed of the three systems. The National Assembly initially had only secondary legislative powers in specific matters (previously in the Secretary of State's portfolio), whilst the Westminster Parliament retained legislative competence in all other matters (Rawlings, 1998).

First generation devolution has not happened in a political vacuum. It has its roots in historic claims for self-government and self-rule in the Celtic regions and also in the administrative decentralization epitomised by the creation of the Scottish Office and the Wales Office in Whitehall (1881 and 1964 respectively) that dealt with local affairs in Scotland and Wales. Secondly, devolution has also been linked with the rise of regionalism in Europe that created an impetus and acted as a catalyst for calls to address the democratic deficit in the Celtic nations (Bogdanor, 2003; Rawlings, 2003), thus bringing government closer to the citizens (Burrows, 2000).

In practice, devolution has been extremely fluid and is still unfolding in the United Kingdom, thus living up to the expectations or premonition of the former Secretary of State for Wales Ron Davies when he famously described it as a 'process not an event'. From a constitutional perspective, the set-up of new legislatures in Scotland, Wales and Northern Ireland meant that new polities, or political spaces were created, deriving their legitimacy from a series of Acts of Parliament and referendums. To date, the constitutional settlements for Scotland and Wales in particular have withstood a great deal of change and adaptation, seeking to absorb the inherent changes and challenges posed by the dynamics of new political spaces. In Scotland, the drive for independence and the continuous public and political deliberative exercise over it constitutional future, culminated with a referendum in Autumn 2014, which produced support (yet not overwhelming) for a place in the Union rather than outside it. In Wales, the constitutional flux was more focused on redressing the inadequacies of the initial set-up and on constitutional alignment with Scotland (Stirbu, 2015). 
Following the Scottish Independence Referendum in 2014 and the upsurge in support for the Scottish Nationalist Party the devolution rhetoric shifted dramatically across the UK. The devolved administrations in Edinburgh and Cardiff have been calling for constitutional protection of their legislatures and for various degrees of income tax devolution and fiscal powers, whilst the UK Government has been pushing a rather top-down, yet uncoordinated set of reforms to the governance of England, which include devolution deals for English cities or combined authorities and a significant reform in the local government financing system (Stirbu, 2015).

The political and policy landscape of the UK was in 2015 much more diverse than it was two decades ago. No less than four different electoral systems are used to elect representatives at local (the Single Transferable Vote is used in Scotland), regional (the Additional Member System is used in Scotland and Wales), national (First-Past-the-Post) and European (regional lists) levels. Minority and coalition governments have become the norm rather than the exception in Scotland and Wales, where nationalist parties are or have been in government (SNP in Scotland since 2007), or in coalition (Plaid Cymru and Labour in Wales 2007-2011) (Seyd, 2004; McAllister, 2007; Osmond, 2007).

Furthermore, public policy in Britain has undergone some diversification due to devolution (Adams and Robinson, 2002; Adams and Schmuecker, 2006; Keating, 2003, 2005; Keating and McEwan, 2006), the policies of devolved governments often departing from the Whitehall policy line (for example on tuition fees in Scotland and Wales, free prescriptions and bus travel in Wales, free personal care for the elderly in Scotland). And lastly, of interest to this paper, the policy making process has also suffered some diversification as well. Various academic studies highlight innovations in the policy arena made by parliamentary committees in Scotland and Wales and their significant contribution to policy (Arter, 2004; McAllister and Stirbu, 2007b; Keating, 2010). Similarly, the devolved administrations seem to be more inclusive in their decision making; public engagement and participation being highlighted as one of the significant advancements through devolution in Wales and Scotland (Stirbu and McAllister, 2011).

As mentioned previously, devolution - a process, not an event - has been extremely fluid. This dynamic, manifested through constant negotiation and renegotiation between London and the periphery of the policy competence boundaries, powers and institutional infrastructures supporting devolution deepened the process to a great extent. To illustrate this, the debates around the financial aspects of elected and non-elected politicians' activity (Hansard Society, 2009; Roger Jones IRP Report, 2009) have brought proportional representation, reform of the House of Lords, and reform of the House of Commons to the political agenda, whilst unveiling significant differences in the way the institutions in Wales and Scotland dealt with the issue of expenses, as opposed to Westminster. There are a lot of examples of policy crossovers and cross-fertilization.

This confirms, to an extent, devolution's experimentation and innovation capacity (McAllister and Stirbu, 2007b). However, the questions that arise are: Has the policy landscape, both in terms of the process and the outcome, been changed significantly through devolution? And what are the major challenges and opportunities that these new spaces for change present us with? And finally, 
are there any lessons transitional countries or countries undergoing both constitutional and administrative reforms can learn from the UK Experience?

In order to answer these questions, this paper is going to focus on the impact of devolution on the policy making process and outcome in Wales. This paper will investigate, through a series of cases and examples, how constitutional arrangements in Wales created and facilitated new policy practices (via extended and compulsory consultation processes with the civil society etc.) which in turn led to policy diversification between Wales and the rest of the UK

\section{Conceptualising spatial policy changes in Britain}

The link between major constitutional changes and policy making is not always straightforward. However, in the case of devolution, as it is with other similar reforms such as regionalization and decentralisation, the links are more than obvious. Academic literature on federalism and regionalism has long proposed the argument that territorial units in federal structures act as laboratories for democracy (Galle and Leahy, 2009) thus opening up the potential for the development of radically different policy practices between the constituent regions (Mooney et al., 2006).

From a British perspective, most of the academic literature on policy making in the UK has mainly used three theoretical approaches to understanding and improving it. The Westminster model, an analytical framework proposing a clear separation between policy and administration (policy is made by the elected politicians and carried out by civil servants) is based on assumptions of simple plurality, with governments carrying out their electoral promises in the policies they formulate (Keating, 2010). The model is helpful in understanding various aspects of Whitehall departments' policy making but does not account for more recent transformation in the policy sphere, completely disregarding notions of public participation and policy deliberation.

The rational model, proposed by Hogwood and Gun (1984), sees policy making a rational staged approach, where various decision-making actors intervene so that they solve particular policy problems or achieve specific policy goals. This model is particularly useful in understanding the different phases in the policy process and allows for flexible interpretations on who intervenes in the process, and how.

The incremental model of policy making is arguably a pragmatic theorization of what happens in practice in the policy arena. Governments' ability to follow the rational model religiously is hindered by the complexity of modern day governance, by the scarcity of time and resources and by the institutional entrenchment and path dependency. The focus is on small steps of 'what it works' rather than leaps of faith into what rational evaluation and research says (Gregory, 1989).

All three models are only partially helpful in explaining the complexities of policy making and public service delivery in the UK post-devolution. There are significant limitations in all of them, particularly when it comes to explaining the various features of the policy landscapes in Scotland and Wales, for instance, post devolution. 
Multi-level governance theories (see Hooghe and Marks, 2001) might come in handy in this case as they account for the existence of various policy communities across the different levels of government and also for the type of intergovernmental relations that exist between the central government and the territorial units (Dente, 1997). Multi-level governance includes a body of theoretical work that seeks to explain the dynamics in modern governance of states and supranational organisations. Dente (1997) uses a three layer categorisation of federal or quasi federal arrangements in order to explain the link between various power sharing models and the socio-economic complexities of the context. His categorisation includes: the co-ordinate / layer cake federalist model, which implies clear demarcation and independence of the jurisdictions at state and federal level. This model is often associated with stable socio-economic and political contexts. The second model proposed is the co-operative federalism, to be found in mostly transitional contexts, and competitive federalism, a model which implied competition between the various level of government for power, resources and legitimacy. The later model characterises a turbulent context. Other interpretations of multi-level governance - governance spread across multiple levels of authority, have been used to explain the emergence of the European Union and the deepening of the European Union integration process (Hooghe and Marks, 2001). Hooghe and Marks define a two-fold typology of multi-level governance relations and focus on the core-periphery dynamic (2001). Their typology is determined by the centrifugal and centripetal forces that act within the governance infrastructure - forces that see power being concentrated towards the centre / core, whilst the periphery follows - centripetal; and forces that see power, authority and decision-making migrating from the centre towards the periphery - centrifugal forces (Hooghe and Marks, 2003). These forces are not static within a complex political system and, in line with other theories on European integration (see the supra-nationalism vs inter-governmentalism debates), the momentum swings between the two driving forces, thus favouring the centre or the periphery. This implies a constant negotiation and re-negotiation of the governance terms in a given political context.

Multi-level governance can thus be a starting point in explaining and contextualising the process of devolution in the UK and, more importantly, in explaining its inherent fluidity and impact on the policy arena. Bache and Flinders (2004) as well as Bulmer et al (2002) have opened the road to such investigation already.

Next, this paper will outline the main features at constitutional, institutional and policy level in the UK, with a focus on Scotland and Wales - reported to the rest of the UK. This overview focuses on the impact these arrangements have had on the policy arena. However, a word of caution is necessary here: this is not an impact study using crude measurement of indicators but an institutionalist overview linking theory and practice in the UK's devolution practice.

\section{Devolved powers and competencies:}

new policy arenas created

Devolution in the UK is asymmetrical; this means that the constituent regions have competencies to act in various areas to different degrees. The devolu- 
tion model in Scotland is a reserved powers model, implying that the Scottish parliament has competency to act in all policy areas (transport, education, justice, health etc), except for those reserved by Westminster (such as defence, monetary policy, constitutional affairs etc). Welsh devolution however, has operated on very different parameters, in a conferred powers model - the Welsh Assembly has power to act only on certain clearly specified policy areas, all the rest being retained by Westminster. The Draft Wales Bill 2015 proposes changes that would bring Wales onto a reserved power model similar to Scotland.

What has been the significance of this asymmetric power sharing model in the UK on the policy making process? Firstly, it meant that Scotland and Wales dealt with different systemic constraints in the development of their policy making. The Welsh model, strung by complexity and cumbersomeness, has been and still is, due to the way the powers were transferred, heavily reliant on Westminster and Whitehall. From a policy perspective, the model requires not only the Welsh ministers and civil servants to carefully navigate the legal and constitutional boundaries of the policy area, but for their Whitehall counterparts to do the same, so that they do not act on areas in which the Assembly has competency. Any policy decision stemming from a Whitehall department is bound to have an impact on Wales (unless stated so deliberately). Thus, an inventory of such powers and competencies is mandatory.

Since the inception of devolution, the Welsh model has presented challenges for policy makers in Whitehall and Cathays Park but also to the parliamentary sides in Cardiff Bay and Westminster. Legislating in unclear areas is time consuming and generates bureaucratic processes that have nothing to do with the substance of policy making but all to do with policing the policy-making process. Moreover, that fact that the Welsh devolution model has suffered the most reviews and transformations to date (i.e. the move from corporate body structure to parliamentary structure, enhanced legislative powers via Legislative competence orders, a referendum on primary powers) meant that intergovernmental relations between Cardiff and London have been more prominent and the negotiation and renegotiation of devolution boundaries between Wales and the UK has been a constant feature of devolution. The Draft Wales Bill proposals, put forward by the Secretary of State for Wales in October 2015, and the criticism it attracted from all sides of the political spectrum (National Assembly Presiding Officer, 2015; CLA Committee, 2015) in Wales as well as from academics (McAllister and Stirbu, 2015) signal that Welsh devolution is still far from a long lasting settlement. There are obviously policy implications for this; first, in terms of clarity of policy and jurisdictional boundaries between Wales and England; and second, in terms of policy instruments available to the Welsh Government to enforce its distinctive legislation.

From a Scottish perspective, the unfolding of the devolution process there brought different challenges and opportunities. Scotland had the 'luxury' of a clear cut model that allowed the Scottish Parliament to flex its muscles in terms of designing new, Scottish fit for purpose policies. The expectations over policy differentiation between Edinburgh and London have been great from the start. Keating (2010) highlights significant differences that took place at the institutional level 
of policy making. However, Cairney (2004) and others point out that in terms of policy divergence devolution has been rather evolutionary than revolutionary. Nonetheless, politically, the Scottish Independence referendum in 2014 and the subsequent surge in support for the Scottish National Party under the new leadership of Nicola Sturgeon, offer a clear indication of Scotland's distinctiveness within the Union. The policy implications of this political distinctiveness are visible in the SNP's visible opposition to the London based Conservative government's continued austerity programme in the UK, a sentiment that is echoed to an extent in Wales as well (White, 2015).

To sum up, in as far as the Welsh developments have been focused more on redressing constitutional abnormalities than on devising a radically different policy context in Wales, Scotland has struggled with rather great and self-imposed expectations. Having said that, one feature present in both countries has been the bargaining over new and more robust powers. This bargaining has taken different forms: in Wales it was mostly about institutional re-adjustment, whereas in Scotland the debate has been more political.

\section{Devolved governments}

The policy epicentre in both Scotland and Wales, post devolution, lies in their devolved governments, the Scottish Government and the Welsh Government respectively. Institutionally, these are descending directly from the Scotland Office and the Wales Office. Moreover, given that the devolution process did not extend to the civil service, and that system still operates on the Unity of the British Civil Service, the Scottish and Welsh governments, at administrative levels have inherited a lot of the practices of Whitehall.

Keating (2010) argues that there is a significant degree of differentiation in the policy making machinery between Edinburgh and London. The Scottish Government has made a clear move towards a new policy focus that aligns administrative responsibilities with policy problems for instance. Similarly, the way the Scottish Government Senior Civil Service is organised, with much shorter lines of communication than in Whitehall, means that since 2007, when the SNP came into power, the hierarchy in decision making has been significantly reduced (Keating, 2010). This creates a series of opportunities in the Scottish Government. First, policies can be developed across directorates, thus adopting a more holistic approach that is in fact practically possible in Whitehall (given the way departments are set-up and how the chain of communication and decision making operates). Secondly, given the strong links that Scottish government has with policy, communities and networks in Scotland, one can argue that there is scope for more evidence based policy making. The role of local government in Scotland is also important as a source of policy advice (Keating, 2010).

As far as challenges are concerned, the biggest challenge faced by the new policy makers in Scotland has arguably been the lack of policy capacity existent in Scottish government. Therefore, the criticism that Scotland has not been innovative enough in the first year of devolution in terms of creating policy diverging from those of Westminster, have the roots in this capacity deficit experienced by the Scottish Government (executive at that time) and the Scottish 
Parliament. The Scottish Executive has sought to redress that since 2006 and the initiative took a new impetus with the election of the SNP government in 2007. Training on the policy skills of civil servants has been introduced into the Scottish government since 2006 .

From a Welsh perspective, the experience of the first years of devolution has been different. The Welsh government, given its limited powers and the systemic constitutional constraints faced in its first four terms, has been branded as innovative in navigating the murky waters of the newly emerged Welsh policy landscape. In contrast with Scotland, some academics have branded some of the Welsh achievement in policy as more innovative. Policy initiatives, such the creation of the Children's Commissioner for Wales, have been applauded and will soon be adopted by the Scottish counterparts for instance (Williams, 2003; Birrell, 2009).

\section{Role of the legislatures}

Arguably, legislature's role in policy making is extremely limited in executive dominated majoritarian systems. Their role in making legislation is confined to scrutinising and embedding government proposals, rather than initiating policy proposals themselves. However, devolution in the UK presents us with an interesting case of parliamentary committees becoming more involved actors in the policy arena. In Wales in particular, the set-up of the National Assembly with only limited executive functions -hence, no legislative pressures- and with committees that joined scrutiny and policy development roles, meant that the policy making machinery in Wales was augmented. Previous studies into the Assembly's subject committees' policy development role show that these have been extremely innovative in the way they contributed to the policy making process (McAllister and Stirbu, 2007b). The committees have virtually created new venues of policy deliberation, separate from those of the Welsh government. Policy deliberation also took a very different form, focusing on evidence-based policy making, involvement of stake-holders, openness and transparency of the process, as well as a commitment to inclusiveness. The committees covered areas that normally escape the interest of government. Some of the most notable policy inquiries conducted by the Welsh subject committees included a review of the governance of football in Wales and a review of dance, for instance. Welsh committees can also initiate legislation and, coupled with the Assembly's standing orders and its precedents in allowing more committee and private member initiated legislation to pass through the Assembly (more so than any other legislature in the UK), the policy arena in Wales has been surprisingly diversified.

Nonetheless, the small capacity of the Assembly (a very small size, only 60 members) has acted as a recurring hindrance. The small pool of members has to cover wide areas of policy portfolios and struggle with multiple memberships to committees. Capacity issues have featured as a main weakness of the Welsh devolution model (McAllister and Stirbu, 2007b; Bates, 2003; Osmond, 2004, Richard Commission 20041 Silk Commission, 2014).

To sum up, the infrastructure supporting the policy in Wales and in Scotland is becoming more robust and has exhibited a series of innovative features. At the heart of these new policy arenas sits a commitment towards inclusiveness. 


\section{Service integration}

One of the most significant departures of devolved government in Scotland and Wales from the UK norms of agentification has been the reform of delegated governance in the new polities, mainly addressing the issue of non-departmental public bodies exercising government functions. Critics of the quango-land mention lack of transparency and accountability as the prime concerns (Birrel 2008). Scotland and Wales have pursued similar policies in tackling quangos, with variable results. The Welsh Government's decision to bring three of Wales' most important quangos in-house in 2004 - the Welsh Development Agency (WDA), in charge of economic development; the Welsh Tourist Board (WTB)and the Education and Learning Wales (ELWa) - was criticised for the lack of consultation, transparency and thorough analysis as regards to the effects of burdening an already overloaded state (McAllister, 2009).

Birrel (2008) too argues that the rationalisation and democratisation of the delegated governance sphere had rather limited outcomes in the devolved administrations. This raises the question about the strategic capacity of the new governments to carefully map out an optimal distribution of government functions in their new polities. Wales in particular has struggled with capacity deficits on multiple levels. An added dimension in Wales was the limited capacity of the Welsh voluntary sector as well at the outset of devolution (Cole, McAllister and Stirbu, 2013). Nonetheless, some of these capacity issues have been overcome by the statutory duty of the Assembly (and the Government) to work in partnership with the voluntary sector, business sector and local government.

Nonetheless, a rationalisation of delegated governance can create different opportunities, ranging from an increase in the capacity of the devolved governments by pulling resources together, to increased accountability and increased strategic capacity overall.

\section{Conclusion}

This article has presented an overview of effects of devolution on the policy framework at the fringes of the policy landscapes in the UK, focusing on Wales and Scotland. The devolution process has been advocated as a far reaching constitutional reform in the United Kingdom. Apart from the political and constitutional asymmetric institutional arrangements that devolution generated, and the fluidity associated with it (i.e. the deepening of the process by extending the degree of self-rule in the home nations, and the various changes undergone by the political institutions especially in Wales), one significant consequence of the devolution process is in regards to the policy making and the policy delivery process.

This article concentrated on highlighting the extent to which the new Welsh and Scottish political spheres have acted as laboratories for democracy and to what extent innovation has been facilitated in the home nations. Throughout this investigation, we have found that the new political spaces in Wales and Scotland do present a series of significant variants from the UK / England level. From a policy making perspective, devolution has created new political and administrative arenas, new spaces for change, with new political actors exercising their power and 
competence. The policy space has not only been fragmented on a territorial basis but undergone significant changes at process and institutional levels.

First, the rhetoric on the policy making arena has been focused on not only doing things differently from Westminster but also on aiming to have different outcomes in terms of policy. The debate over policy divergence/convergence in the UK as a result of devolution has been extremely heated in academic circles. Significant divergence in terms of policy making institutional arrangements has been evidenced in both Scotland and Wales (McGarvey \& Shephard, 2002; Loughlin \& Skyes, 2004). Despite inheriting a policy making machinery so deeply rooted in Whitehall practices, the devolved administrations have managed to achieve a certain degree of separateness and differentiation from their London counterparts. In Wales, for instance, this has a lot to do with the fact that the principle of partnership between the Welsh Government and its social partners (voluntary sector, business sector and local government) was enshrined in Wales' first constitutional document (the Government of Wales Act 1998) making it mandatory.

Secondly, devolution has arguably created more differentiation in process rather than outcome in policy. Both Scotland and Wales have adapted their policy making infrastructure and have pioneered new public engagement practices for instance; the policy making machinery in both countries operates on a more holistic level, with policy being developed across themes and the chains of command and communication being shorter that in Whitehall.

Thirdly, the asymmetry in devolution presented some challenges but also opportunities. There are examples of successful policy learning and transfer between administrations. However, the flaws in the original design of the devolution settlements meant that a lot of the focus, especially in Wales, has been on redressing some constitutional anomalies rather than on developing fit for purpose policies for Wales. Moreover, the new decentralisation dynamics in England, pursued without a strategic and coherent analysis of the whole of the UK policy framework risks introducing further fragmentation. Whilst this can foster innovation, the lack of the democratic renewal element in England might pose serious challenges to public accountability and scrutiny.

Fourthly, without disputing the democratic value of devolution and without undermining the inclusiveness focus of policy making in Scotland and Wales, there is not sufficient evidence to support the claim that devolution has made public service delivery in Wales and Scotland more efficient and effective. The devolution dividend, however quantified, did not seem to have reached the Welsh people for instance (Price, 2015). The failure of the Welsh government to reduce NHS waiting list times in Wales is particularly notable.

There are particular lessons that we can draw from the UK's experience with asymmetric territorial devolution. Firstly, asymmetry can be a catalyst for experimentation and innovation. Secondly, the success of any form of decentralisation will be dependent on the policy and the institutional capacity of the constituent units. Thirdly, path dependency can hinder the development of new practices especially when the devolution of power does not permeate the political party system and the civil service. 


\section{REFERENCES}

1. Adams, J. \& Robinson, P. (2002). Devolution in Practice: Public Policy Differences within the United Kingdom, London: IPPR.

2. Adams, J. \& Schmuecker, K. (2006). Devolution in Practice 2006: Public Policy Differences within the UK, London: IPPR.

3. Arter, D. (2004). The Scottish Parliament: A Scandinavian-Style Assembly, London: Frank Cass.

4. Bache, I. (2007). Europeanization and Multilevel Governance: Cohesion Policy in the European Union and Britain. Rowman \& Littlefield Publishers.

5. Bache, I. \& Flinders, M. (2004). Multi-level Governance. Oxford University Press.

6. Bache, I. \& Marshall, A. (2004). Europeanisation and Domestic Change: A Governance Approach to Institutional Adaptation in Britain (n. p0046). Queen's University Belfast.

7. Benz, A. \& Eberlein, B. (1999). The Europeanization of Regional Policies: Patterns of Multi-Level Governance. Journal of European Public Policy, vol. 6, n. 2, pp. 329-348.

8. Birrell, D. (2008). Devolution and Quangos in the United Kingdom: the Implementation of Principles and Policies for Rationalisation and Democratisation. Policy Studies, vol. 29, n. 1, pp. 35-49.

9. Birrell, D. (2009). The impact of devolution on social policy. Bristol: The Policy Press.

10. Bogdanor, V. (2003). Asymmetric Devolution: Toward a Quasi-Federal Constitution?. Developments in British Politics, n. 7, pp. 222-41.

11. Bovaird, T. (2006). Developing New Forms of Partnership with the 'Market' in the Procurement of Public Services. Public Administration, vol. 84, n. 1, pp. 81-102.

12. Bulmer, S., Burch, M., Carter, C., Hogwood, P., \& Scott, A. (2002). British Devolution and European Policy-Making: Transforming Britain into Multi-Level Governance. Basingstoke, UK: Palgrave Macmillan.

13. Burrows, N. (2000). Devolution. London: Sweet \& Maxwell.

14. Cairney, P. (2004). Convergence and Divergence following Devolution in Scotland: An Implementation Agenda. Paper to Centre for Public Policy and Management, Glasgow Caledonian University, n. 22.

15. CLA Committee. 2015. Constitutional and Legislative Affairs Committee Report on Pre-Legislative Scrutiny of the Draft Wales Bill, National Assembly for Wales. Available: URL: http://www.assembly.wales/laid\%20documents/cr-ld10468/cr-ld10468-e.pdf (accessed: 15 December, 2015). 
16. Cole, M., McAllister, L. \& Stirbu, D. (2014). The Capacity of the National Assembly. In: Osmond (ed.) A Stable, Sustainable Settlement for Wales, UK Changing the Union partnership, Cardiff, Available: URL: http://ukchangingunion.org.uk/en/wp-content/ uploads/2013/02/ChangingUnion_Complete.pdf (accessed: 15 December, 2015).

17. Dente, B. (1997). Sub-national Governments in the Long Italian Transition. West European Politics, vol. 20, n. 1, pp. 176-193.

18. Flynn, N. (2002). Explaining the New Public Management: the Importance of Context. In: The New Public Management: Current Trends and Future Prospects. London: Routledge, pp. 57-76.

19. Flynn, N. (2007). Public Sector Management. London: Sage.

20. Galle, B.D., \& Leahy, J. K. (2009). Laboratories of Democracy? Policy Innovation in Decentralized Governments. Emory Law Journal, vol. 58, n. 6, pp. 1333-1400.

21. Gregory, R. (1989). Political Rationality or 'Incrementalism'? Charles E. Lindblom's Enduring Contribution to Public Policy Making Theory. Policy \& Politics, vol. 17, n. 2, pp. 139-153.

22. Hogwood, B. W., \& Gunn, L.A. (1984). Policy Analysis for the Real World (Vol. 69). Oxford: Oxford University Press.

23. Hooghe, L. (ed.) (1996). Cohesion Policy and European Integration: Building MultiLevel Governance. Oxford: Oxford University Press.

24. Hooghe, L., \& Marks, G. (2001). Multi-level Governance and European Integration. Lanham, M.D.: Rowman \& Littlefield.

25. Keating, M. (2010). The Government of Scotland: Public Policy Making after Devolution. Edinburgh: Edinburgh University Press.

26. Keating, M. \& McEwen, N. (2006). Devolution and Public Policy, London: Routledge.

27. Keating, M. (2003). Social Inclusion, Devolution and Policy Divergence. Political Quarterly, vol. 74, pp. 429-438.

28. Keating, M. (2005). Policy Making and Policy Divergence in Scotland after Devolution. (Devolution Briefings, n. 21), Birmingham: ESRC Devolution Programme.

29. Loughlin, J., \& Sykes, S. (2004). Devolution and Policy-Making in Wales: Restructuring the System and Reinforcing Identity. Policy Papers, n. 11.

30. McAllister, L., \& Stirbu, D.S. (2007a). Opportunities for Gender Innovations in a New Political Space. International Journal of the Interdisciplinary Social Sciences, vol. 1, n. 1, pp. 1-11.

31. McAllister, L., \& Stirbu, D. (2007b). Developing Devolution's Scrutiny Potential: a Comparative Evaluation of the National Assembly for Wales's Subject Committees. Policy \& Politics, vol. 35, n. 2, pp. 289-309. 
32. McAllister, L., \& Stirbu, D.S. (2008). Influence, Impact and Legacy-Assessing the Richard Commission's Contribution to Wales's Evolving Constitution. Representation, vol. 44, n. 3, pp. 209-224.

33. McAllister, L. \& Stirbu, D.S. (2015). Evidence to the Welsh Affairs Committee on Pre-Legislative Scrutiny of the Draft Wales Bill. Available: URL: http://www.senedd. cynulliad.cymru/documents/s46557/DWB\%2015\%20-\%20Laura\%20McAllister\%20a\%20Diana\%20Stirbu.pdf (accessed: 20 December, 2015).

34. McAllister, L. (2007). Welsh Politics is Tottering towards a Brave New World of Shared Power, The Western Mail, 7 July.

35. McAllister, L. (2009). Cutting Quangos: Let's Learn a Lesson from Wales Aberdare Online Available: http://www.aberdareonline.co.uk/node/11287 (accessed: 20 December, 2015).

36. McGarvey, N., \& Shephard, M. (2002) Policy Outputs in Scotland: Devolution or Duplication. In: Political Studies Association Annual Conference. 5-7 April. University of Aberdeen.

37. Mooney, G., Scott, G., \& Williams, C. (2006). Introduction: Rethinking Social Policy through Devolution. Critical Social Policy, vol. 26, n. 3, pp. 483-497.

38. Osborne, D., \& Gaebler, T. (1992). Reinventing Government: How the Entrepreneurial Spirit is Transforming Government. Reading, Massachusetts: Addison-Wesley.

39. Osmond, J. (2004). Size Matters, Summer Agenda: The Journal of the Institute of Welsh Affairs, pp. 32-33.

40. Osmond, J. (2007). Crossing The Rubicon: Coalition Politics Welsh Style, Cardiff: Institute Of Welsh Affairs.

41. Pestoff, V., Brandsen, T. \& Verschuere, B. (eds.). (2013). New Public Governance, the Third Sector, and Co-Production. (Vol. 7). London: Routledge.

42. PO National Assembly for Wales, 2015. Letter in Support of the Presiding Officer's Response to the UK Government Draft Wales Bill. Available: http://www.assembly. wales/deposited\%20papers/dp-1481-11-16/dp-1481-11-16.pdf (accessed: 20 December, 2015).

43. Price, A. (2015). The One and a Half Party State, Available: http://www.clickonwales. org/2015/10/the-one-and-a-half-party-state/ (accessed: 20 December, 2015).

44. Rawlings, R. (1998). The New Model Wales. Journal of Law and Society, vol. 25, n. 4, pp. 461-509.

45. Rawlings, R.W. (2003). Delineating Wales: Constitutional, Legal and Administrative Aspects of National Devolution. University of Wales Press, pp. 1-644.

46. Rhodes, R.A.W. (1996). The New Governance: Governing without Government. Political Studies, vol. 44, n. 4, pp. 652-667. 
47. Seyd, B. (2004). Coalition Government in Scotland and Wales. London: The Constitution Unit.

48. Stirbu, D.S. (2009). Instituting Constitutions: Welsh Constitutional Dynamics and the Development of the National Assembly for Wales 2005-2007. Contemporary Wales, vol. 22, n. 1, pp. 95-112.

49. Stirbu, D. (2015). A devolution Revolution, Briefing for LexisNexis.

50. Stirbu, D., \& McAllister, L. (2011). An Exercise in Democratic Deliberation: The All Wales Convention's Contribution to Constitutional Change. Contemporary Wales, vol. 24, n. 1, pp. 64-85.

51. Webb, D., \& Collis, C. (2000). Regional Development Agencies and the 'New Regionalism' in England. Regional Studies, vol. 34, n. 9, pp. 857-864.

52. White, J. (2015). When Parties Make Peoples. Global Policy, vol. 6, n. S1, pp. 106-114.

53. Williams, C. (2003). The Impact of Labour on Policies for Children and Young People in Wales. Children \& Society, vol. 17, n. 3, pp. 247-253. 